Board of Governors of the Federal Reserve System

International Finance Discussion Papers

Number 946

September 2008

\title{
Emerging Market Business Cycles with Remittance Fluctuations
}

\author{
Ceyhun Bora Durdu \\ Serdar Sayan
}

NOTE: International Finance Discussion Papers are preliminary materials circulated to stimulate discussion and critical comment. References in publications to International Finance Discussion Papers (other than an acknowledgment that the writer has had access to unpublished material) should be cleared with the author or authors. Recent IFDPs are available on the Web at www.federalreserve.gov/pubs/ifdp/. This paper can be downloaded without charge from Social Science Research Network electronic library at http://www.ssrn.com/. 


\title{
Emerging Market Business Cycles with Remittance Fluctuations
}

\author{
Ceyhun Bora Durdu \\ Federal Reserve Board \\ Serdar Sayan \\ TOBB University of Economics and Technology
}

\begin{abstract}
This paper analyzes the implications of remittance fluctuations for various macroeconomic variables and Sudden Stops. The paper employs a quantitative two-sector model of a small open economy with financial frictions calibrated to Mexican and Turkish economies, two major recipients, whose remittance receipts feature opposite cyclical characteristics. We find that remittances dampen the business cycles in Mexico, whereas they amplify the cycles in Turkey. Their quantitative effects in the long run, approximated by the stochastic steady state are mild. In the short run, however, remittances have quantitatively large impacts on the economy, when the economy is borrowing constrained. This is because agents in the economy cannot adjust their precautionary wealth to sudden tightening in credit, hence, fluctuations in remittances get magnified through an endogenous debt-deflation mechanism. Our findings suggest that procyclical (or countercyclical) remittances can play a significant deepening (or mitigating) role for Sudden Stops.
\end{abstract}

Keywords: Business cycles, Remittances, Sudden Stops

JEL Codes: F41, F32, E44

* Author notes: We would like to thank Pedro Silos, and the participants of the Remittances and the Macroeconomy conference at the Atlanta FED for useful comments. The views in this paper are solely the responsibility of the author(s) and should not be interpreted as reflecting the views of the Board of Governors of the Federal Reserve System or an any other person associated with the Federal Reserve System. The email addresses of the authors are bora.durdu@frb.gov, serdar.sayan@etu.edu.tr 


\title{
Emerging Market Business Cycles with Remittance Fluctuations
}

\author{
Ceyhun Bora Durdu \\ Federal Reserve Board \\ Serdar Sayan \\ TOBB University of Economics and Technology
}

\begin{abstract}
This paper analyzes the implications of remittance fluctuations for various macroeconomic variables and Sudden Stops. The paper employs a quantitative two-sector model of a small open economy with financial frictions calibrated to Mexican and Turkish economies, two major recipients, whose remittance receipts feature opposite cyclical characteristics. We find that remittances dampen the business cycles in Mexico, whereas they amplify the cycles in Turkey. Their quantitative effects in the long run, approximated by the stochastic steady state are mild. In the short run, however, remittances have quantitatively large impacts on the economy, when the economy is borrowing constrained. This is because agents in the economy cannot adjust their precautionary wealth to sudden tightening in credit, hence, fluctuations in remittances get magnified through an endogenous debt-deflation mechanism. Our findings suggest that procyclical (or countercyclical) remittances can play a significant deepening (or mitigating) role for Sudden Stops.
\end{abstract}

Keywords: Business cycles, Remittances, Sudden Stops

JEL Codes: F41, F32, E44

* Author notes: We would like to thank Pedro Silos, and the participants of the Remittances and the Macroeconomy conference at the Atlanta FED for useful comments. The views in this paper are solely the responsibility of the author(s) and should not be interpreted as reflecting the views of the Board of Governors of the Federal Reserve System or an any other person associated with the Federal Reserve System. The email addresses of the authors are bora.durdu@frb.gov, serdar.sayan@etu.edu.tr 


\title{
Emerging Market Business Cycles with Remittance Fluctuations*
}

\author{
Ceyhun Bora Durdu ${ }^{\dagger}$ \\ Federal Reserve Board
}

\author{
Serdar Sayan \\ TOBB University of \\ Economics and Technology
}

September 2008

\begin{abstract}
This paper analyzes the implications of remittance fluctuations for various macroeconomic variables and Sudden Stops. The paper employs a quantitative two-sector model of a small open economy with financial frictions calibrated to Mexican and Turkish economies, two major recipients, whose remittance receipts feature opposite cyclical characteristics. We find that remittances dampen the business cycles in Mexico, whereas they amplify the cycles in Turkey. Their quantitative effects in the long run, approximated by the stochastic steady state are mild. In the short run, however, remittances have quantitatively large impacts on the economy, when the economy is borrowing constrained. This is because agents in the economy cannot adjust their precautionary wealth to sudden tightening in credit, hence, fluctuations in remittances get magnified through an endogenous debt-deflation mechanism. Our findings suggest that procyclical (or countercyclical) remittances can play a significant deepening (or mitigating) role for Sudden Stops.
\end{abstract}

JEL Classification: F41, F32, E32

Keywords: Business cycles, Remittances, Sudden Stops

*We would like to thank Ayhan Köse, Pedro Silos, an anonymous referee, and the participants of the Remittances and the Macroeconomy conference at the Atlanta FED for useful comments. The views in this paper are solely the responsibility of the author(s) and should not be interpreted as reflecting the views of the Board of Governors of the Federal Reserve System or an any other person associated with the Federal Reserve System.

$\dagger$ Corresponding Address: Federal Reserve Board, the Division of International Finance, Washington, D.C. 20551. E-mail: bora.durdu@frb.gov. Tel: (202)452-3755. 


\section{Introduction}

Officially recorded migrant remittances received by developing countries increased to $\$ 250$ billion in 2007, representing a 50 percent increase in just three years since 2005 by the World Bank estimates. ${ }^{1}$ Thanks to this fast growth, the total amount officially received by the developing world has more than tripled in nominal terms since the beginning of this decade. This growth has been visibly faster than the growth of private capital flows and official development assistance (ODA), enabling remittances to eventually surpass non-FDI (private debt and portfolio equity) and ODA flows, and to almost catch FDI receipts in magnitude as of $2004 .^{2}$ As a result, remittances have become a more important source of foreign exchange than private capital flows, ODA and even FDI for many developing countries. Popular stance in the policy circles and the academic literature is to view this rapid growth as a generally positive development for developing economies on account of the following:

1. In contrast to other capital flows, remittances do not create any liabilities such as debt servicing or profit transfers in the future.

2. Remittance flows are usually more stable than private capital flows including FDI (Ratha, 2003; Buch and Kuckulenz, 2004).

3. Remittances could serve as macroeconomic stabilizers, as it is often argued, since migrant workers are likely to increase the amounts transferred to help family members left behind, whenever the economic activity back home slows down (UNCTAD, 2006; World Bank, $2006 \mathrm{a}$ and b).

4. Remittance receipts may promote entrepreneurship, investment in physical capital and human capital formation, by helping relax borrowing constraints facing family members that stayed home (Yang, 2008).

Yet, whether high remittance receipts are always a blessing depends on the nature of comovements, if any, between business cycles in the home countries of migrants and cyclical fluctuations in the remittance flows. Remittances will move countercyclically to output fluctuations

\footnotetext{
${ }^{1}$ By the definition in the World Bank's Global Development Finance 2003, migrant remittances are made up of workers' remittances, compensation of employees, and migrants' transfers.

${ }^{2}$ During the same year, remittance receipts exceeded combined public and private capital inflows in 36 developing countries and were larger than total merchandise exports in 12 others. In some countries such as Mexico, FDI receipts often fall short of remittances (World Bank, 2006a).
} 
in the home countries of migrant workers, if the dominant motivation behind their remitting decisions is to contribute to the financing of consumption expenditures of family members left behind (the so-called altruistic consumption-smoothing motive). ${ }^{3}$ However, an increasing number of studies after Sayan (2004) have pointed out the possibility of procyclical remittances due to investment or portfolio-diversification motive - see, for example, Lueth and Ruiz-Arranz (2007) and papers cited therein. ${ }^{4}$

Regardless of the underlying motivation to remit, remittances could be a blessing, if they move counter to home country business cycles, as they will then serve as macroeconomic stabilizers against cyclical contractions or Sudden Stops (see, for example, Bugamelli and Paternò, 2005). If they are procyclical, on the other hand, they could be a setback as the drops in remittance receipts observed during cyclical contractions or Sudden Stops would magnify the damage resulting from such contractions or stops. Answers to how effective countercyclical or procyclical remittance flows could be in lowering or increasing the amplitude of macroeconomic fluctuations depend on several factors and hence are less obvious. In addition to the nature of co-movements between remittance fluctuations and business cycles, the response time of remittances to business cycle movements, and the share of remittances in GDP need to be taken into consideration while answering this question. Likewise, the quantitative effects that remittance fluctuations could have on different macroeconomic variables during Sudden Stops experienced by the recipient economies need to be investigated quantitatively, using an appropriate model that captures general equilibrium interactions between key macroeconomic variables.

We aim to shed light on these issues by examining the effect of remittance flows with opposite cyclical characteristics on different macroeconomic aggregates and Sudden Stops. ${ }^{5}$ For this purpose, we introduce remittances into the small open economy model of Mendoza (2005) and calibrate it to the data for the Mexican and Turkish economies, two major recipients which differ with regard to the way remittance receipts respond to respective home country business cycles. Remittances are procyclical in Turkey, whereas they are countercyclical in Mexico, as

\footnotetext{
${ }^{3}$ In this case, household members working abroad would increase the amounts they remit when there is a recession/crisis in the home economy so as to help compensate the decline in household income due to unemployment and wage cuts that family members may face during such episodes.

${ }^{4}$ Sayan (2006) presented evidence showing that remittances are procyclical in some countries and listed a number of possible reasons underlying this procyclicality. Our results also confirm that cyclical characteristics of remittances may be different across countries (see Figures 1 and 2, Table 1, which are generated using data in constant local currency units, i.e., real terms).

${ }^{5}$ In a recent, cross-country study, Bugamelli and Paternò (2005) find that as cheap inflows of foreign currencies, remittances might reduce the probability that foreign investors suddenly flee out of emerging markets and developing economies and trigger a dramatic current account adjustment.
} 
thoroughly discussed by Sayan and Tekin-Koru (2008a).

The model features a tradable sector and a nontradable sector in which the liabilities are denominated in units of tradable goods, (i.e., liabilities are dollarized), and agents face a borrowing constraint in international capital markets. Foreign debt is partially leveraged through income generated in the nontradable sector. Interaction of these two frictions, i.e., liability dollarization and the borrowing constraint, creates a debt deflation mechanism that mimics the key features of Sudden Stops experienced by both Mexico and Turkey. In the absence of remittances, a shock to the economy making the borrowing constraint binding leads to a decline in tradable consumption and relative price of nontradables. The decline in relative price of nontradables tightens the constraint even further because the collateral value of nontradable income becomes lower. Further tightening of the borrowing constraint creates a feedback mechanism, which eventually leads to a collapse in consumption and relative price of nontradables and reversals in current account. ${ }^{6}$ Using this model, we quantitatively explore how important the remittance fluctuations are to countries where they move countercyclically and procyclically to domestic business cycles, and investigate possible effects of these fluctuations on Sudden Stops experienced by such countries.

Our results indicate that remittances dampen the business cycles in the Mexican economy, whereas they deepen the cycles in the Turkish economy as expected. Their quantitative effects in the long run approximated by the stochastic steady state are rather mild, and do not significantly depend on whether the economy is borrowing constrained or not. ${ }^{7}$ In the short run, however, remittances can have quantitatively large impacts on the macroeconomy, if the borrowing constraints are binding. In the short run, agents in the economy cannot adjust their precautionary wealth to sudden tightening of credit, causing small remittance shocks to the economy to get magnified through the endogenous debt-deflation mechanism.

We quantify the short-run impact effects of remittance fluctuations using forecasting functions. $^{8}$ We compare the impact effect of income shocks with and without the accompanying remittance shocks. In the Turkish case, a one-standard-deviation negative remittance shock that accompanies a one-standard-deviation income shock magnifies the decline in tradable con-

\footnotetext{
${ }^{6}$ Various studies (Caballero and Krishnamurthy, 2001; Calvo, Izquierdo and Mejía, 2005; Mendoza 2002, among others) showed that such credit crunches amplified by highly dollarized liabilities were the main driving force of the Sudden Stops that emerging markets like Mexico and Turkey faced during the last decade and a half. It is merely this mechanism in the model that generates Sudden Stop-like crises dynamics.

${ }^{7}$ This result mimics the findings of Mendoza (2002), who finds that imposition of borrowing constraints do not alter the long run business cycles quantitatively, because agents engage in precautionary savings and minimize the impacts of borrowing constraints on the macroeconomy in the long-run.

${ }^{8}$ Forecast functions are a variant of impulse response functions, which are derived by setting the initial conditions of the economy to a state where the economy is prone to a Sudden Stop.
} 
sumption by 2 percent and the reversal in current account-GDP ratio by 3 percentage points. In the Mexican case, a one-standard deviation positive remittance shock that follows the negative income shock smooths the decline in tradable consumption by 1.4 percent and decreases the reversal in the current account-GDP ratio by 2 percentage points. These results suggest that remittances can have significant amplifying, in the case of procyclical remittances, or smoothing, in the case of countercyclical remittances, effects on Sudden Stops.

Despite their significance, the current literature lacks studies on such effects of remittances except through cross-country regressions (see, for example, Bugamelli and Paternò, 2006). ${ }^{9}$ Furthermore, the existing studies largely focus on the effects of countercyclical remittances on the volatility of output, consumption and investment in the recipient countries (see, for example, IMF, 2005), and overlook the macroeconomic effects of procyclical remittance flows that individual countries such as Turkey may receive. This paper provides a first look at these issues using a dynamic stochastic general equilibrium model with Sudden Stops. ${ }^{10}$ In addition to our work, there are a limited number of studies that use a stochastic general equilibrium framework to explore the effects of remittances on different macroeconomic variables in small open economy settings, but none of them focuses on Sudden Stops. Chami, Cosimano and Gapen (2006), and Jansen, Naufal and Vacaflores (2008) investigate the effects of remittances on key macroeconomic variables, and the conduct of fiscal/monetary policies by using the same countercyclical specification which relates changes in remittances to output so that they would increase when there is a downturn in the recipient economy. Acosta, Lartey and Mandelman (2007) consider the effects of altruistically motivated (countercyclical) and investment oriented (procyclical) remittances separately but in contrast to the present study, they focus on the effects of remittances through their potential to cause Dutch disease.

Prior to these studies, Chami, Fullenkamp, and Jahjah (2003) used a model with micro foundations to formalize the argument about the altruism of migrants as the underlying reason for the countercyclicality of remittances, and backed this theoretical result with panel data evidence indicating that remittances respond negatively to changes in output. Later, other studies such as IMF (2005), Mishra (2005) and World Bank (2006a and b) presented additional evidence indicating a negative relationship between output and remittance receipts. Yet, the first look in

\footnotetext{
${ }^{9}$ See, also, Aguinas, 2006 for an extensive review of this literature

${ }^{10}$ In a recent, cross-country study, Bugamelli and Paternò (2005) find that as cheap inflows of foreign currencies, remittances might reduce the probability that foreign investors suddenly flee out of emerging markets and developing economies and trigger a dramatic current account adjustment.
} 
the literature by Sayan (2004) at the co-movements between the cyclical components (defined as deviations from trend) of home country output and remittances series produced different results. Using quarterly time series data on remittances sent home by Turkish workers in Germany, Sayan (2004) found that remittance receipts of Turkey from Germany were procyclical. ${ }^{11}$ More recently, Sayan and Tekin-Koru (2008a) considered the cyclical behavior of Turkish remittances from Germany and Mexican remittances from the US in a comparative study. Using quarterly data covering the 1980s onwards, they found that remittance receipts of Mexico from the US were synchronously countercyclical to the business cycle in Mexico, whereas Turkish remittances were again procyclical and followed the business cycle in Turkey with a one-quarter lag. ${ }^{12}$

In addition to the literature on remittances, our work is also related the literature on business cycle fluctuations in small open economies as exemplified by the works of Durdu, Mendoza and Terrones (2007), Durdu (2006), Durdu and Mendoza (2006), Neumeyer and Perri (2005), Kose (2002) and Mendoza (1991, 2002, 2005), among others. Mendoza (1991) provides a workhorse quantitative small open economy model that accounts for the aggregate fluctuations in small open economies. Kose (2002) extends this model to explore the importance of world price shocks and fluctuations in world interest rates on business cycles of small open economies. Neumeyer and Perri (2005) focus on the importance of world interest rates in driving business cycles. Our paper relates to this first group of papers by shedding some light on the business cycle implications of remittance fluctuations. Mendoza (2002, 2005), among others, emphasizes the role of frictions in the world capital markets and accounts for the observed features of Sudden Stops. Durdu (2006) examines how hedging and self-insurance options and their implications for Sudden Stops are affected if the agents have access to GDP-indexed credit contracts. This paper contributes to this literature by examining the quantitative importance of remittance fluctuations on Sudden Stops by employing the features used in those studies.

The discussion in the rest of the paper is organized as follows. Section 2 describes the model, Section 3 presents the results of the quantitative exercises, and Section 4 concludes.

\footnotetext{
${ }^{11}$ The sharp drop in remittance receipts to Turkey during the 2001 crisis conformed to these findings (Ratha, 2003). Using a larger country sample, Sayan (2006) provided additional support to the view that non-altrusitic considerations may drive the remittance behavior, leading to procyclical remittances. These findings are in line with the intuition that Buch, Kuckulenz and Le Manchec (2002) and Ratha (2003) previously pointed out.

${ }^{12}$ Sayan and Tekin-Koru (2008b) offered the stagnation of Turkish migration to Germany in the 1980s after family reunifications as the most plausible explanation for the procyclicality of remittances. Turkish migrants' ties with the family members remaining in Turkey weakened with the passage of time, they argued, causing altruism motive to lose its strength. For Mexico, on the other hand, this motive must remain strong as migration of Mexican workers to the US continues, albeit mostly illegally.
} 


\section{Model}

We introduce remittances to the two sector small open economy model of Mendoza (2005). Foreign debt is denominated in units of tradables and imperfect credit markets impose a borrowing constraint that limits external debt to a share of the value of total income in units of tradables.

Representative households receive stochastic exogenous remittances denoted $\left(1+\varepsilon_{t}^{R}\right)$ Rem; a stochastic endowment of tradables and a nonstochastic endowment of nontradables, which are denoted $\left(1+\varepsilon_{t}^{y}\right) y^{T}$ and $y^{N}$, respectively. $\varepsilon_{t}^{R}$ and $\varepsilon_{t}^{y}$ are respective shocks to the remittances and tradables endowments. Households derive utility from aggregate consumption $(c)$, and they maximize the following stationary cardinal utility function:

$$
U=E_{0}\left\{\sum_{t=0}^{\infty} \exp \left[-\sum_{\tau=0}^{t-1} \gamma \log \left(1+c_{t}\right)\right] u\left(c_{t}\right)\right\}
$$

Functional forms are given by:

$$
\begin{gathered}
u\left(c_{t}\right)=\frac{c_{t}^{1-\sigma}-1}{1-\sigma} \\
c_{t}\left(c_{t}^{T}, c_{t}^{N}\right)=\left[\omega\left(c_{t}^{T}\right)^{-\mu}+(1-\omega)\left(c_{t}^{N}\right)^{-\mu}\right]^{-\frac{1}{\mu}} .
\end{gathered}
$$

The instantaneous utility function is in constant relative risk aversion (CRRA) form with an inter-temporal elasticity of substitution value of $1 / \sigma$. Aggregate consumption is given by a constant elasticity of substitution (CES) function, where $1 /(1+\mu)$ is the elasticity of substitution between consumption of tradables and non-tradables and where $\omega$ is the CES weighing factor. $\exp \left[-\sum_{\tau=0}^{t-1} \gamma \log \left(1+c_{t}\right)\right]$ is an endogenous discount factor that is introduced to induce stationarity in consumption and asset dynamics. $\gamma$ is the elasticity of the subjective discount factor with respect to consumption. ${ }^{13}$

The households' budget constraint is:

$$
c_{t}^{T}+p_{t}^{N} c_{t}^{N}=\left(1+\varepsilon_{t}^{R}\right) \operatorname{Rem}+\left(1+\varepsilon_{t}^{y}\right) y^{T}+p_{t}^{N} y^{N}-b_{t+1}+(1+r) b_{t}
$$

where $b_{t}$ is current bond holdings, $(1+r)$ is the gross return on bonds, and $p_{t}^{N}$ is relative price of non-tradables. Notice that bond returns are denominated in units of tradables whereas they are partially financed by income earned in nontradable sector, i.e., liabilities are dollarized.

\footnotetext{
${ }^{13}$ Mendoza, 1991 first introduced preferences with endogenous discounting to quantitative small open economy models. See Schmitt-Grohé and Uribe (2003); and Kim and Kose (2003) for alternative specifications used for this purpose.
} 
In addition to the budget constraint, foreign creditors impose the following borrowing constraint, which limits debt issuance as a share of total income at period $t$ not to exceed $\kappa$. Moreover, the bond holdings cannot be lower than a minimum level, $\Omega:^{14}$

$$
b_{t+1} \geq-\kappa\left[\left(1+\varepsilon_{t}^{R}\right) \operatorname{Rem}+\left(1+\varepsilon_{t}\right) y^{T}+p_{t}^{N} y^{N}\right] \geq \Omega
$$

The borrowing constraint takes a similar form to those used in the Sudden Stops literature (see for example, Mendoza, 2005; Caballero and Panageas, 2003; among others). The interaction of the borrowing constraint with the liability dollarization induces a debt deflation mechanism that amplifies the shocks to the economy. (See Mendoza, 2005 for further details.)

The optimality conditions can be summarized as follows:

$$
\begin{aligned}
U_{c}(t)\left(1-\frac{\nu_{t}}{\lambda_{t}}\right)= & \exp \left[-\gamma \log \left(1+c_{t}\right)\right] E_{t}\left\{\frac{(1+r) p_{t}^{c}}{p_{t+1}^{c}} U_{c}(t+1)\right\}, \\
& \frac{1-\omega}{\omega}\left(\frac{c_{t}^{T}}{c_{t}^{N}}\right)^{1+\mu}=p_{t}^{N},
\end{aligned}
$$

along with the budget constraint (Equation 4), the borrowing constraint (Equation 5), and the standard Kuhn-Tucker conditions. $\nu$ and $\lambda$ are the Lagrange multipliers of the borrowing constraint and the budget constraint, respectively. $U_{c}$ is the derivative of lifetime utility with respect to aggregate consumption. $p_{t}^{c}$ is the CES price index of aggregate consumption in units of tradable consumption, which equals $\left[\omega^{\frac{1}{\mu+1}}+(1-\omega)^{\frac{1}{\mu+1}}\left(p^{N}\right)^{\frac{\mu}{\mu+1}}\right]^{\frac{1+\mu}{\mu}}$. Equation (6) is the standard Euler equation equating marginal utility at time $t$ to that of time $t+1$. Equation (7) equates the marginal rate of substitution between tradables consumption and non-tradables consumption to the relative price of non-tradables.

This endowment economy model is certainly not less powerful than a model with capital accumulation in terms of its capacity to explain sudden stop dynamics. One needs an amplification mechanism to generate sudden stop dynamics, and the amplification is generated through the interaction of the borrowing constraint with the relative price of nontradables in our setup. This amplification can alternatively be generated through the borrowing price of capital in a model with capital accumulation. Given that the magnitude of the amplification in this endowment economy is as high as the one with capital accumulation(see Durdu et. al 2008, Mendoza 2002,

\footnotetext{
${ }^{14}$ This lower bound for bond holdings (or upper bound for debt level) is introduced to rule out equilibria in which the constraint is satisfied at very high levels of debt that increase $c^{T}$ and $p^{N}$. See Mendoza (2005) for further details.
} 
2005), however, we opt for the simpler endowment economy setup.

Concerning the cyclical characteristics of remittances, we take the procyclical or countercyclical nature of the remittances in Turkey and Mexico as given by the data and analyze their implications on macroeconomic aggregates, instead of delving into possible reasons and different motivations to remit underlying these characteristics. Sayan (2006), for example, points out that how much to remit is a complex decision involving many other factors than the migrants' altruistic desire to help family members smooth their consumption, and different variables driving remittance behavior might be differently affected by the state of economic activity over home country business cycles. ${ }^{15}$ The response of remittance flows to cyclical fluctuations in economic activity at home is indeed likely to be different, when remittances are primarily motivated by the differences in rates of return to savings in home and host countries of migrant workers (investment or portfolio-diversification motive). In such a case, upturns in economic activity may be associated with an increase in remittance receipts of the home country economy, whereas a downturn may lower these receipts, producing a procyclical remittance behavior. Thus, the response of remittance flows to cyclical output movements may differ, depending upon whether investment (or portfolio-diversification) motive is stronger than the altruistic consumption-smoothing motive for the migrant workers from different countries. Furthermore, which motive is stronger may change over time as the migrants' ties with relatives back home get weaker -due to increasing duration of stay in the host country and/or reunification of the migrants and immediate family members in the country of employment etc. (Sayan and Tekin-Koru, 2008b). The passage of time may also allow remittance-receiving households to save enough to switch from wage earners to small entrepreneurs, possibly causing the remittance behavior of the family members abroad to change. Such a change in the labor force participation status of recipient households may also occur due to savings made possible by positive remittance shocks, since such remittance shocks often serve to relax borrowing constraints facing households in developing countries as argued by Yang (2008). ${ }^{16}$

The next section presents the results of a series of numerical exercises that explore the implications of remittance fluctuations.

\footnotetext{
${ }^{15}$ See, for example, Russel (1986) for a list of factors that may affect remittance flows.

${ }^{16}$ As a matter of fact, remittance receipts of households from abroad often increase in domestic currency terms due to depreciation of local currency during recessions/crises, even if the amounts remitted stay the same in foreign currency terms. If the increase in remittance in receipts in domestic currency more than compensates for the loss in household income, this may cause the labor force participation behavior of household members at home from wage earners to self-employed, as discussed by Yang (2008) within the context of the effects of the Asian crisis on the remittances from Filipino workers working abroad (see also Funkhouser, 1992).
} 


\section{Quantitative Analysis}

The recursive representation of the households' problem can be formulated as follows:

$$
\begin{aligned}
V(b, \varepsilon) & =\max _{b^{\prime}}\left\{u(c)+(1+c)^{-\gamma} E\left[V\left(b^{\prime}, \varepsilon^{\prime}\right)\right]\right\} \quad \text { s.t. } \\
c^{T} & =\left(1+\varepsilon^{R}\right) \operatorname{Rem}+\left(1+\varepsilon^{y}\right) y^{T}-b^{\prime}+R b, \\
c^{N} & =y^{N}, \\
b^{\prime} & \geq-\kappa\left[\left(1+\varepsilon^{R}\right) \operatorname{Rem}+\left(1+\varepsilon^{y}\right) y^{T}+p^{N} y^{N}\right] \geq \Omega .
\end{aligned}
$$

Here $\mathcal{B}=\left\{b_{1}<\ldots<b_{N B}\right\}$ is the endogenous state space. $\mathcal{E}=\left\{\varepsilon^{R}, \varepsilon^{y}\right\}$ is the exogenous state space, which follows a joint Markov process with known vectors of realization. To approximate the Markov process for those exogenous shocks, we, first, estimate a vector-autoregression (VAR) of tradable output and remittance series. Then we estimate the Markov transition matrix using Tauchen and Hussey's (1991) quadrature procedure. The VAR representation of the system can be summarized as follows:

$$
\xi_{t}=R H O \cdot \xi_{t-1}+e_{t}
$$

where

$$
\xi_{t} \equiv\left[\begin{array}{c}
\varepsilon^{y} \\
\varepsilon^{R}
\end{array}\right], \quad R H O=\left[\begin{array}{cc}
\rho_{y} & \rho_{y, R} \\
\rho_{R, y} & \rho_{R}
\end{array}\right], \quad e_{t} \equiv\left[\begin{array}{c}
e_{t}^{y} \\
e_{t}^{R}
\end{array}\right]
$$

We calibrate the model to both Turkish and Mexican economies. Statistics in Table 1 suggest that the remittance fluctuations are procyclical in Turkey whereas they are countercyclical in Mexico. The parameter values are summarized in Table 2. Parameters common for both countries are relative risk aversion parameter, which is set to 2; world interest rate, which is set to the quarterly equivalent of 6.5 percent, and the elasticity of substitution between tradable and nontradable goods, which is set to 0.316 following the estimates of Ostry and Reinhart (1992). The relative price of nontradables and mean tradable endowments are normalized to 1 for both countries. The rest of the parameters are country specific as summarized in the table. The estimated VAR coefficients for Turkey are

$$
R H O=\left[\begin{array}{ll}
0.580 & 0.016 \\
1.484 & 0.365
\end{array}\right]
$$


with the standard deviation of the endowment shock equal to 0.035 and of the remittance shock equal to 0.207. The VAR coefficients for Mexico are

$$
R H O=\left[\begin{array}{cc}
0.687 & -0.023 \\
-1.070 & 0.200
\end{array}\right]
$$

with the standard deviation of the endowment shock equals 0.027 and of the remittance shock equals 0.124 .

We solve the stochastic simulations using value function iteration over a discrete state space. The state space spans $[-5.0,3.0]$ interval with 1,000 grid points for both calibrations to Mexico and Turkey. We employ the solution procedure described in Durdu (2006) and Mendoza (2002). We start with an initial conjecture for the value-function and solve the model without imposing the borrowing constraint. We then check whether the bond decision satisfies the borrowing constraint. If so, the solution is found and we calculate the implied value-function, which is then used as a conjecture for the next iteration. If not, we impose the borrowing constraint with equality and solve it again. Then, we calculate the implied value-function using the optimal bond holdings and iterate to convergence.

We divide the stochastic simulations into four sets. In the first set, which we call Baseline $N B$ (for "no borrowing contraint"), the borrowing constraint does not bind and the economy is hit by both endowment and remittance shocks. In the second set, which is labeled Baseline $B$, the economy is hit by both the endowment and remittance shocks again, but it, now, faces a borrowing constraint. In the third set, the economy is hit by an endowment shock only, and the borrowing constraint does not bind. This set is labeled End. Shock NB, accordingly. In the last set, called End. Shock B, the economy is hit by endowment shock only, and the borrowing constraint binds. These simulation exercises aim to shed light on how significant a role remittances play in macroeconomic fluctuations and Sudden Stops.

Figures 3 and 4 show the ergodic distribution of bond holdings in the binding economies with and without remittance shocks for Turkey and Mexico, respectively. Those figures illustrate that remittances shocks increase the precautionary savings for Turkey as the distribution for the Baseline B is more to the right compared to the distribution for End. Shock B. For Mexico, however, remittances shocks decrease the precautionary savings due to their countercyclical nature. Notice that the distribution for Baseline B for Mexico is to the left of End. Shock B.

Table 3 summarizes the long run business cycle statistics for Turkey. In the nonbinding case, 
the elimination of procyclical remittance fluctuations reduces the volatility of consumption from 1.77 percent to 1.51 percent. In line with this change, the volatility of aggregate consumption, the volatility of relative price of nontradables, and the volatility of savings also decline. Procyclical remittance fluctuations lead to stronger comovement of consumption with income (compare, for instance, the correlation of tradable consumption with GDP standing at 0.72 in the baseline case with the respective correlation of 0.67 in the endowment shock only case). Overall, remittances fluctuations reduce welfare by 0.16 percent in the nonbinding case, and 0.27 percent in the binding case. ${ }^{17}$ The table also illustrates the strengthening effect of remittance fluctuations on precautionary savings. This strengthening effect arises because remittance fluctuations reduce the catastrophic income levels. ${ }^{18}$

Table 4 summarizes the long run business cycle statistics for Mexico. Contrary to the Turkish case, remittance fluctuations dampen the cycles in the Mexican economy because of their countercyclical nature. In the nonbinding case, volatility of consumption falls to 1.18 percent in the baseline case compared to the high of 1.40 percent in the economy with endowment shock only. In line with that result, correlation of tradable consumption with GDP increases from 0.74 in the baseline case to 0.78 in the economy with endowment shock only. Overall, the remittances fluctuations increase welfare by 0.0166 percent in the nonbinding economy and 0.0312 in the binding economy. As in the case for Turkey, imposition of the borrowing constraint does not change the direction of the changes as a result of remittance fluctuations.

Since emerging countries are typically borrowing constrained and the borrowing constraints in the economy get tighter on the eve of a financial crisis, an exogenous shock that can be smoothed with foreign borrowing can lead to a Sudden Stop in such economies. With occasionally binding borrowing constraints in place, our model can generate Sudden Stops, allowing us to explore how remittance fluctuations affect Sudden Stops by analyzing model dynamics. ${ }^{19}$ For this purpose, we use forecasting functions. To derive those functions, conditional on the economy being in a state in which the borrowing constraint binds, we first give a one standard deviation negative

\footnotetext{
${ }^{17}$ Welfare calculations are performed using a compensating variation metric in consumption that equate expected lifetime utilities with and without remittance fluctuations.

${ }^{18}$ Aiyagari (1994) shows the relationship between the catastrophic income levels and precautionary savings behavior. In his analysis, he establishes that risk averse agents have strong incentives to build up precautionary wealth to insure against the risk of state of natures in which the income stays its lowest level forever, i.e., income is at its catastrophic level. He also shows that if a structural change in the economy such as more volatile and/or more persistent income shocks reduces the catastrophic income levels, precautionary savings that agents in the economy engage in would increase (see Aiyagari, 1994, Durdu, 2006 and Durdu et. al., 2007 for further analysis of the relationship between catastrophic income levels and precautionary savings).

${ }^{19}$ Sudden Stops are modeled using the same mechanism as in Mendoza (2002).
} 
tradable endowment shock and derive the response in End. Shock NB economy, and then we simultaneously give a one-standard-deviation negative endowment shock and a one-standarddeviation remittance shock and derive the response of the baseline NB economy. We choose the nature of remittance shocks by considering the opposing cyclical characteristics of remittances in Turkey and Mexico. We follow the same steps for the binding economies, as well. By taking the differences between these responses, we can calculate the additional response that remittance shocks trigger.

Figure 5 plots the conditional forecasting functions of aggregate consumption, tradable consumption, current account-GDP ratio and relative price of nontradables for Turkey. In the nonbinding cases, additional (negative) remittance shocks trigger mild additional responses (notice how close solid lines in Figure 5 are to the zero line). In the binding cases, however, remittance shocks trigger much larger additional responses. For example, remittance shocks lead to around 2 percent additional decline in tradable consumption, around 8 percent additional decline in aggregate consumption, around 3 percent additional surplus in current account-GDP ratio, and 0.7 percent additional decline in relative price of nontradables. These results suggest that on the eve of a financial crisis, remittance shocks can have a significant effect on the economy, as the borrowing constraints in the economy get tighter and small additional shocks get magnified by a Fisherian debt deflation process. (See Mendoza, 2005 for further analysis of Fisherian debt deflation.)

Figure 6 plots the conditional forecasting function for Mexico. In this exercise, we compare the effect of a negative endowment shock alone with that of a negative endowment shock together with a positive remittance shock by considering the countercyclical nature of remittances in Mexico. In line with the results for the Turkish case, when the economy is not borrowing constrained, the remittance shocks do not alter the responses in the economy significantly. When the economy is borrowing constrained, however, positive remittance shocks provide a significant smoothing effect. For example, the positive remittance shock helps reduce the decline in tradable consumption by about 1.4 percent, that in aggregate consumption and relative price of nontradables by around around 6 percent and 0.5 percent, respectively, while smoothing current account reversal by about 2 percentage points. 


\section{Conclusion}

Recently presented evidence indicates that remittances sent home by Turkish workers abroad move in the same direction as the business cycles in Turkey, whereas remittance receipts of Mexico are countercyclical. Given the procyclicality of remittances received by Turkey, drops in the amounts remitted by migrant Turkish workers during or shortly after cyclical contractions in Turkish GDP will tend to fan the flames of a crisis in the Turkish economy, whereas countercyclical remittances from migrant Mexican workers will tone down a crisis in the Mexican economy. Yet, the existing literature is largely silent about the magnitude of the effects of remittances on cyclical volatility of output and other macroeconomic variables, as well as Sudden Stops, particularly in the case of countries whose remittance receipts fluctuate procyclically.

This paper aimed to close this gap in the literature by exploring the effects of migrants' remittances flows with opposite responses to business cycle fluctuations in the recipient economies on key macroeconomic aggregates and Sudden Stops experienced by these countries. For this purpose, we considered Mexico and Turkey, two emerging economies that rank among the major recipients of remittances, whose receipts are countercyclical and procyclical to home business cycles, respectively. We employed a general equilibrium framework with a tradable and a nontradable sector to model small open economies of Mexico and Turkey. We allowed for dollarization of the liabilities and let agents face a borrowing constraint in international capital markets for added realism in capturing the common structural characteristics of Mexican and Turkish economies. After calibrating this model to the data for each economy, we ran four different simulation experiments involving an endowment and a remittance shock for each country, under binding and non-binding borrowing constraint scenarios. Our results indicated the following:

- Remittances dampen the cycles in Mexico, whereas they amplify the cycles in Turkey.

- Long run effects of remittances do not significantly depend on the existence of borrowing constraints, but their short run effects depend on whether the economy is borrowing constrained or not.

- Fisherian debt-deflation can magnify the effects of fluctuations in remittances in the short run in both countries.

- Countercyclical (or procyclical) remittance fluctuations can help to reduce precautionary savings by increasing (or reducing) catastrophic income levels. 
- On the eve of a financial crisis, remittances packages received from abroad could significantly reduce (or increase) the impact effect of financial crises if the remittances are countercyclical (or procyclical), implying that it could indeed pour, when it rains in the case of procyclical remittances (as Kaminsky, Reinhart and Végh put it in their 2004 study on procylical capital flows).

These findings provide a rationale for the importance of remittances in mitigating macroeconomic fluctuations and Sudden Stops. While helping to close an important gap in the literature, our study did not explore the migrants' decision on how much and when to remit, i.e., what makes remittances procyclical or countercyclical. We rather took those cyclical properties of remittance fluctuations as given and looked at their implications. To derive these properties, we would need to endogenize the altruistic motives for remittance decisions. Albeit interesting, this task is left for further research. 


\section{References}

[1] Acosta, P. A., E. K.K. Lartey, and F. S. Mandelman (2007). "Remittances and the Dutch Disease." Working Paper, Federal Reserve Bank of Atlanta, 2007-8.

[2] Aguinas, D.R. (2006). "Remittances and Development: Trends, Impacts, and Policy Options (A Review of the Literature)." Washington: Migration Policy Research Institute.

[3] Aiyagari, S. R. (1994). "Uninsured Idiosyncratic Risk and Aggregate Saving." Quarterly Journal of Economics, v. 109, No. 3, pp. 17-31.

[4] Buch, C. and A. Kuckulenz (2004). "Worker Remittances and Capital Flows to Developing Countries." Discussion Paper, Centre for European Economic Research, 04-31.

[5] Buch, C.M., A. Kuckulenz, and M. Le Manchec (2002). "Worker Remittances and Capital Flows, Discussion Paper, Kiel Institute for World Economics, 1130.

[6] Bugamelli, M. and F. Paternò (2005). "Do Workers' Remittances Reduce the Probability of Current Account Reversals" World Bank Policy Research Working Paper No. 3766.

[7] Bugamelli, M. and F. Paternò (2006). "Output Volatility and Remittances." Draft, Bank of Italy.

[8] Caballero, R. J. and S. Panageas (2003). "Hedging Sudden Stops and Precautionary Recessions: A Quantitative Framework." Mimeo, MIT.

[9] Calvo, G. A., A. Izquierdo, and L. Mejía, 2004, "On the Empirics of Sudden Stops: The Relevance of Balance-Sheet Effects ," Working Paper, IADB, 509.

[10] Chami, R., T. F. Cosimano, and M. T. Gapen (2006). "Beware of Emigrants Bearing Gifts: Optimal Fiscal and Monetary Policy in the Presence of Remittances." Working Paper, International Monetary Fund, WP/06/61.

[11] Chami, R., C. Fullenkamp, and S. Jahjah (2003). "Are Immigrant Remittance Flows a Source of Capital for Development?" Working Paper, International Monetary Fund, $\mathrm{WP} / 03 / 189$.

[12] Durdu, C. B. (2006). "Quantitative Implications of Indexed Bonds in Small Open Economies." Working Paper, Congressional Budget Office, 2006-12.

[13] Durdu, C. B. and E. G. Mendoza (2006). "Are Asset Price Guarantees Useful for Preventing Sudden Stops?: The Globalization Hazard-Moral Hazard Tradeoff of Asset Price Guarantees." Journal of Inernational Economics, v. 69, pp. 84-119. 
[14] Durdu, C. B., E. G. Mendoza, and M. Terrones (2008). "Precatuionary Demand for Foreign Assets in Sudden Stop Economies: An Assestment of New Merchantalism." Journal of Development Economics, forthcoming.

[15] Funkhouser, E. (1992). "Migration from Nicaragua: Some Recent Evidence." World Development, v. 20(8), pp. 1209-1218.

[16] IMF (2005). World Economic Outlook: Globalization and External Imbalances, Washington: International Monetary Fund.

[17] Jansen, D., G. S. Naufal, and D. Vacaflores (2007). "The Macroeconomic Consequences of Remittances," Paper presented at the conference on "Remittances and the Macroeconomy," Federal Reserve Bank of Atlanta, Feb. 21-22.

[18] Kaminsky, G.L., C.M. Reinhart, and C.A. Vgh, 2004, "When It Rains It Pours: Procyclical Capital Flows and Macroeconomic Policies" in NBER Macroeconomics Annual 2004, ed. by M. Gertler and K. Rogoff, Cambridge: MIT Press, pp. 11-53.

[19] Kim, S. H. and M. A. Kose (2003). "Dynamics of Open-Economy Business-Cycle Models: Role of the Discount Factor." Macroeconomic Dynamics, Cambridge University Press, vol. $7(2)$, pages 263-90.

[20] Kose, M. A. (2002). "Explaining business cycles in small open economies: 'How much do world prices matter?"." Journal of International Economics, v. 56(2), pp. 299-327.

[21] Lane, P. and G. M. Milesi-Ferretti (2001). "The External Wealth of Nations: Measures of Foreign Assets and Liabilities for Industrial and Developing Countries." Journal of International Economics, v. 55, pp. 263-294.

[22] Lueth, E. and M. Ruiz-Arranz (2007). "Are Workers' Remittances a Hedge Against Macroeconomic Shocks? The Case of Sri Lanka," IMF Working Paper No. 07/22.

[23] Mendoza, E. G. (1991). "Real Business Cycles in a Small Open Economy," American Economic Review, v. 81, 797-818, September.

[24] Mendoza, E. G. (2002). "Credit, Prices, and Crashes: Business Cycles with a Sudden Stop" in Preventing Currency Crisis in Emerging Markets, ed. by S. Edwards and J. Frankel, University of Chicago Press.

[25] Mendoza, E. G. (2005). "Real Exchange Rate Volatility and the Price of Nontradables in Sudden-Stop Prone Economies" Economia, fall, pp. 103-148.

[26] Mishra, P. (2005). "Macroeconomic Impact of Remittances in the Caribbean." Unpublished, Washington: International Monetary Fund. 
[27] Neumeyer, P. A. and F. Perri (2005). "Business Cycles in Emerging Economies: the Role of Interest Rates." Journal of Monetary Economics, v. 52, pp. 345-380.

[28] Ostry, J. D. and C. Reinhart (1992). "Private Saving and Terms of Trade Shocks." IMF Staff Papers, v. 39, pp 495-517.

[29] Ratha, D., 2003, "Workers' Remittances: An Important and Stable Source of External Development Finance," (Chapter 7) in Global Development Finance: Striving for Stability in Development Finance, Washington: World Bank, pp. 157-175.

[30] Russell, S. S. (1986). "Remittances from International Migration: A Review in Perspective," World Development, v. 14, pp. 677-696.

[31] Sayan, S. (2004). "Guest Workers' Remittances and Output Fluctuations in Host and Home Countries, pp. The Case of Remittances from Turkish Workers," Emerging Markets Finance and Trade, v. 40(6), pp. 70-84.

[32] Sayan, S. (2006). "Business Cycles and Workers' Remittances: How Do Migrant Workers Respond to Cyclical Movements of GDP at Home?" Working Paper, International Monetary Fund, WP/06/52.

[33] Sayan, S. and A. Tekin-Koru (2008a). "The Effects of Economic Developments and Policies in Host Countries on Workers' Remittance Receipts of Developing Countries: The Cases of Turkey and Mexico Compared," in R. Lucas, L. Squire and T. Srinivasan (eds.), The Impact of Rich Country Policies on Developing Economies. London: Edward Elgar, forthcoming.

[34] Sayan, S. and A. Tekin-Koru (2008b). "Remittances, Business Cycles and Poverty: The Recent Turkish Experience," International Migration, forthcoming.

[35] Tauchen, G. and R. Hussey (1991). "Quadrature-Based Methods for Obtaining Approximate Solutions to Nonlinear Asset Pricing Models." Econometrica, v. 59, no. 2, pp. 371-396.

[36] Schmitt-Grohé, S. and M. Uribe (2003). "Closing Small Open Economy Models." Journal of Inernational Economics, v. 61, pp. 163-185.

[37] UNCTAD (2006). Trade and Development Report, 2006. Geneva: United Nations.

[38] World Bank (2006a). Global Economic Prospects: Economic Implications of Remittances and Migration, Washington: World Bank.

[39] The World Bank (2006b). The Development Impact of Workers' Remittances in Latin America, Report No. 37026 (2 Volumes). Washington: World Bank. 
[40] Yang, D. (2008). "International Migration, Remittances and Household Investment: Evidence from Philippine Migrants' Exchange Rate Shocks." The Economic Journal, v. 118, pp. 591-630. 
Table 1: Business Cycle Facts for Mexico and Turkey

\begin{tabular}{lcccccc}
\hline \hline Variable: $x$ & $\sigma(x)$ & $\sigma(x) / \sigma(Y)$ & $\rho(x)$ & $\rho(x, Y)$ & Sudden Stop & $\begin{array}{c}\text { Sudden Stop } \\
\text { relative to std. }\end{array}$ \\
\hline Mexico & & & & & $1994: 4-1995: 1$ & \\
GDP (Y) & 2.26 & 1.0 & 0.80 & 1.0 & -7.4 & 3.3 \\
tradables GDP & 2.7 & 1.2 & 0.7 & 0.92 & -8.98 & 3.35 \\
nontradables GDP & 2.19 & 0.97 & 0.83 & 0.98 & -6.18 & 2.82 \\
remittance & 12.38 & 5.48 & 0.26 & -0.38 & 6.61 & 0.53 \\
consumption & 4.22 & 1.87 & 0.84 & 0.97 & -11.20 & 2.65 \\
real exchange rate & 8.63 & 3.82 & 0.73 & 0.60 & -32.84 & 3.81 \\
CA/Y & 0.70 & 0.31 & 0.83 & -0.47 & 2.22 & 3.18 \\
Turkey & & & & & $1994: 1-2$ & \\
GDP (Y) & 3.70 & 1.00 & 0.67 & 1.00 & -10.38 & 2.00 \\
tradables GDP & 3.51 & 0.95 & 0.52 & 0.96 & -10.93 & 3.11 \\
nontradables GDP & 4.02 & 1.09 & 0.68 & 0.98 & -10.01 & 2.49 \\
remittance & 20.67 & 5.60 & 0.42 & 0.22 & -30.36 & 1.47 \\
consumption & 4.13 & 1.12 & 0.75 & 0.92 & -10.10 & 2.4 \\
real exchange rate & 9.11 & 2.47 & 0.68 & 0.60 & -31.63 & 3.47 \\
CA/Y & 2.74 & 0.74 & 0.63 & -0.59 & 9.7 & 3.38 \\
\hline
\end{tabular}

Source: Bank of Mexico, Central Bank of Turkey, International Financial Statistics. The data cover periods 1987:Q1-2004:Q4 for both Mexico and Turkey. Data are quarterly seasonally adjusted real series in constant local currency units. Consumption, GDP, and Remittance data are logged and filtered using an HP filter with a smoothing parameter 1600. Real exchange rates are calculated using the IMF definition $\left(R E R_{i}=\right.$ $N E R_{i} \times C P I_{i} / C P I_{U S}$ for country $\left.i\right)$. 
Table 2: Parameter Values

\begin{tabular}{|c|c|c|c|}
\hline Parameter & Value & Definition & Source \\
\hline \multicolumn{4}{|c|}{ General Parameters } \\
\hline$\sigma$ & 2 & Relative risk aversion & $\mathrm{RBC}$ parametrization \\
\hline$y^{T}$ & 1 & Tradable endowment & normalization \\
\hline$R$ & 1.0159 & Gross interest rate & RBC parametrization \\
\hline$\mu$ & 0.316 & Elasticity of substitution & Ostry and Reinhart (1992) \\
\hline$p^{N}$ & 1 & Relative price of NT & Normalization \\
\hline \multicolumn{4}{|c|}{ Country Specific Parameters for Turkey } \\
\hline$y^{N} / y^{T}$ & 1.3418 & Share of NT output & Turkish data \\
\hline $\operatorname{Rem} / G D P$ & 0.03 & Remittance-GDP ratio & Turkish data \\
\hline$\kappa$ & 0.4 & Constraint coefficient & Set to match SS dynamics \\
\hline$\omega$ & 0.4222 & CES weight & Calibration \\
\hline$\gamma$ & 0.0198 & Elasticity of discount factor & Calibration \\
\hline \multicolumn{4}{|c|}{ Country Specific Parameters for Mexico } \\
\hline$y^{N} / y^{T}$ & 1.543 & Share of NT output & Mexican data \\
\hline $\operatorname{Rem} / G D P$ & 0.02 & Remittance-GDP ratio & Mexican data \\
\hline$\kappa$ & 0.4 & Constraint coefficient & Set to match SS dynamics \\
\hline$\omega$ & 0.3723 & CES weight & Calibration \\
\hline$\gamma$ & 0.0187 & Elasticity of discount factor & Calibration \\
\hline
\end{tabular}

Note: This table shows the parameter values used in calibrating the model economies. The first column shows the parameters, the second column shows their values, the third column shows their definition, and the last column shows the source used in calculating those parameters. 
Table 3: Long Run Business Cycle Statistics of the Model Economy Calibrated to Turkey

\begin{tabular}{|c|c|c|c|c|}
\hline & \multicolumn{4}{|c|}{ Economies } \\
\hline & Baseline NB & Baseline B & End. Shock NB & End. Shock B \\
\hline \multicolumn{5}{|l|}{ Means } \\
\hline tradable consumption & 1.06 & 1.07 & 1.06 & 1.07 \\
\hline aggregate consumption & 1.21 & 1.22 & 1.21 & 1.22 \\
\hline relative price of $\mathrm{NT}$ & 1.00 & 1.02 & 1.00 & 1.01 \\
\hline savings & -0.78 & 0.09 & -0.79 & -0.07 \\
\hline current account-GDP ratio & -0.03 & -0.03 & -0.03 & -0.03 \\
\hline welfare $(\%)$ & -0.16 & -0.27 & n.a. & n.a. \\
\hline \multicolumn{5}{|l|}{ Standard Deviation (\%) } \\
\hline tradable consumption & 1.77 & 1.41 & 1.51 & 1.20 \\
\hline aggregate consumption & 0.78 & 0.62 & 0.67 & 0.53 \\
\hline relative price of $\mathrm{NT}$ & 2.33 & 1.86 & 1.99 & 1.58 \\
\hline savings & 97.94 & 60.34 & 84.20 & 52.13 \\
\hline current account-GDP ratio & 1.48 & 1.43 & 1.48 & 1.45 \\
\hline \multicolumn{5}{|l|}{ Correlation with GDP } \\
\hline tradable consumption & 0.72 & 0.70 & 0.68 & 0.65 \\
\hline aggregate consumption & 0.72 & 0.70 & 0.68 & 0.65 \\
\hline relative price of NT & 0.72 & 0.70 & 0.68 & 0.65 \\
\hline savings & 0.68 & 0.60 & 0.62 & 0.56 \\
\hline current account-GDP ratio & 0.74 & 0.77 & 0.80 & 0.82 \\
\hline \multicolumn{5}{|l|}{ Autocorrelation } \\
\hline tradable consumption & 0.99 & 0.97 & 0.99 & 0.97 \\
\hline aggregate consumption & 0.99 & 0.97 & 0.99 & 0.97 \\
\hline relative price of $\mathrm{NT}$ & 0.99 & 0.97 & 0.99 & 0.97 \\
\hline savings & 0.99 & 0.99 & 0.99 & 0.99 \\
\hline current account-GDP ratio & 0.52 & 0.52 & 0.53 & 0.52 \\
\hline
\end{tabular}

Notes: The first column shows the statistics in the model economy with non-binding borrowing constraint and with both the endowment and remittance shocks, the second column shows the statistics in the model economy with binding borrowing constraint and with both the endowment and remittance shocks. The last two columns show the statistics for the respective economies with non-binding and binding borrowing constraints but the endowment shocks only. NB refers to nonbinding economy, and B refers to binding economy. End. refers to endowment. Welfare calculations illustrate how remittance fluctuations affect welfare compared to the "endowment shock only"-case using a compensating variation metric. 
Table 4: Long Run Business Cycle Statistics of the Model Economy Calibrated to Mexico

\begin{tabular}{|c|c|c|c|c|}
\hline & \multicolumn{4}{|c|}{ Economies } \\
\hline & Baseline NB & Baseline B & End. Shock NB & End. Shock B \\
\hline \multicolumn{5}{|l|}{ Means } \\
\hline tradable consumption & 1.04 & 1.05 & 1.04 & 1.05 \\
\hline aggregate consumption & 1.32 & 1.34 & 1.32 & 1.33 \\
\hline relative price of $\mathrm{NT}$ & 1.00 & 1.01 & 1.00 & 1.01 \\
\hline savings & -0.83 & -0.32 & -0.83 & -0.21 \\
\hline current account-GDP ratio & -0.02 & -0.02 & -0.02 & -0.02 \\
\hline welfare $(\%)$ & $1.66 \mathrm{e}-2$ & $3.12 \mathrm{e}-2$ & n.a. & n.a. \\
\hline \multicolumn{5}{|l|}{ Standard Deviation (\%) } \\
\hline tradable consumption & 1.18 & 0.99 & 1.40 & 1.07 \\
\hline aggregate consumption & 0.47 & 0.40 & 0.56 & 0.43 \\
\hline relative price of $\mathrm{NT}$ & 1.55 & 1.30 & 1.84 & 1.40 \\
\hline savings & 63.02 & 42.89 & 78.70 & 48.39 \\
\hline current account-GDP ratio & 1.02 & 1.00 & 1.01 & 1.00 \\
\hline \multicolumn{5}{|l|}{ Correlation with GDP } \\
\hline tradable consumption & 0.74 & 0.72 & 0.78 & 0.74 \\
\hline aggregate consumption & 0.74 & 0.73 & 0.78 & 0.74 \\
\hline relative price of NT & 0.74 & 0.72 & 0.78 & 0.74 \\
\hline savings & 0.66 & 0.60 & 0.71 & 0.63 \\
\hline current account-GDP ratio & 0.75 & 0.78 & 0.71 & 0.76 \\
\hline \multicolumn{5}{|l|}{ Autocorrelation } \\
\hline tradable consumption & 0.97 & 0.95 & 0.99 & 0.97 \\
\hline aggregate consumption & 0.97 & 0.95 & 0.99 & 0.97 \\
\hline relative price of $\mathrm{NT}$ & 0.97 & 0.95 & 0.99 & 0.97 \\
\hline savings & 0.99 & 0.99 & 0.99 & 0.99 \\
\hline current account-GDP ratio & 0.60 & 0.60 & 0.60 & 0.60 \\
\hline
\end{tabular}

Notes: The first column shows the statistics in the model economy with non-binding borrowing constraint and with both the endowment and remittance shocks, the second column shows the statistics in the model economy with binding borrowing constraint and with both the endowment and remittance shocks. The last two columns show the statistics for the respective economies with non-binding and binding borrowing constraints but the endowment shocks only. NB refers to nonbinding economy, and B refers to binding economy. End. refers to endowment. Welfare calculations illustrate how remittance fluctuations affect welfare compared to the "endowment shock only"-case using a compensating variation metric. 
Figure 1: Business Cycles in Turkey
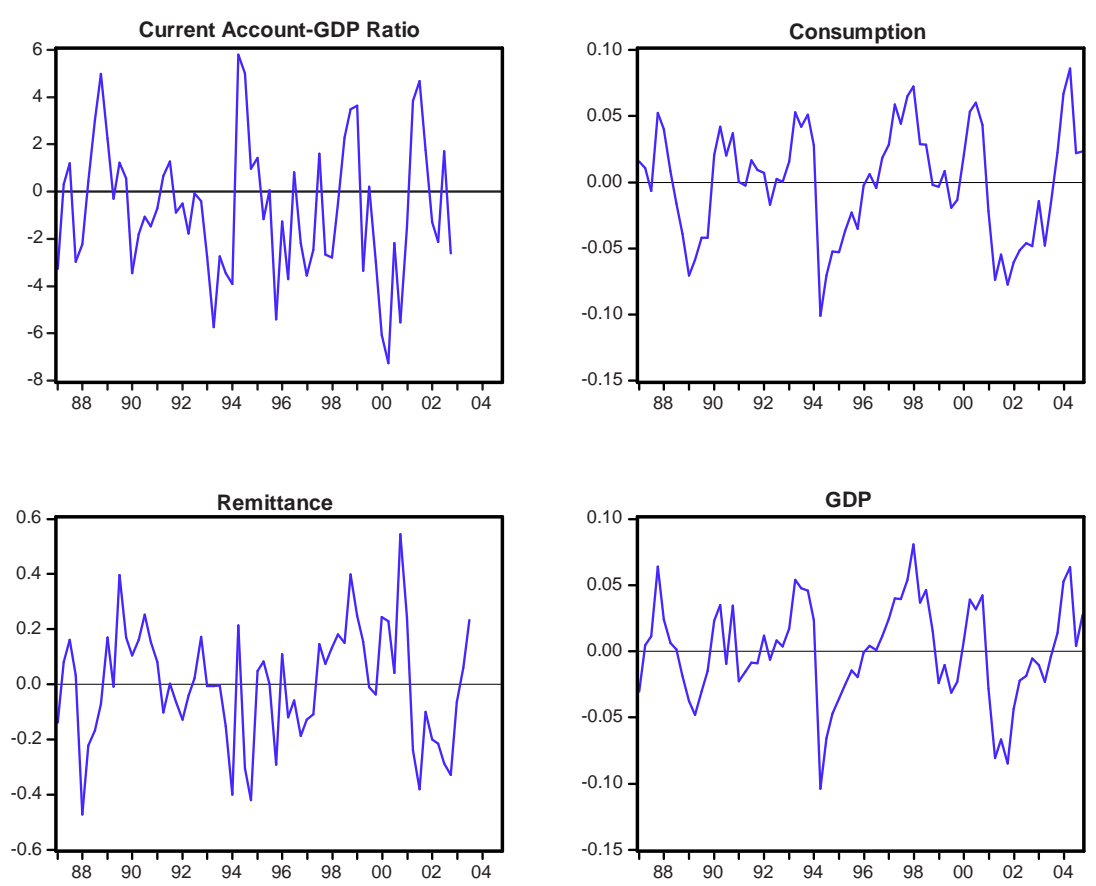

Notes: Data used in the graphs are quarterly seasonally adjusted real series in constant local currency units.

Consumption, GDP, and Remittance data are logged and filtered using an HP filter with a smoothing parameter value of 1600 . The graphs show deviations from trend for these variables over the sample period.

Figure 2: Business Cycles in Mexico
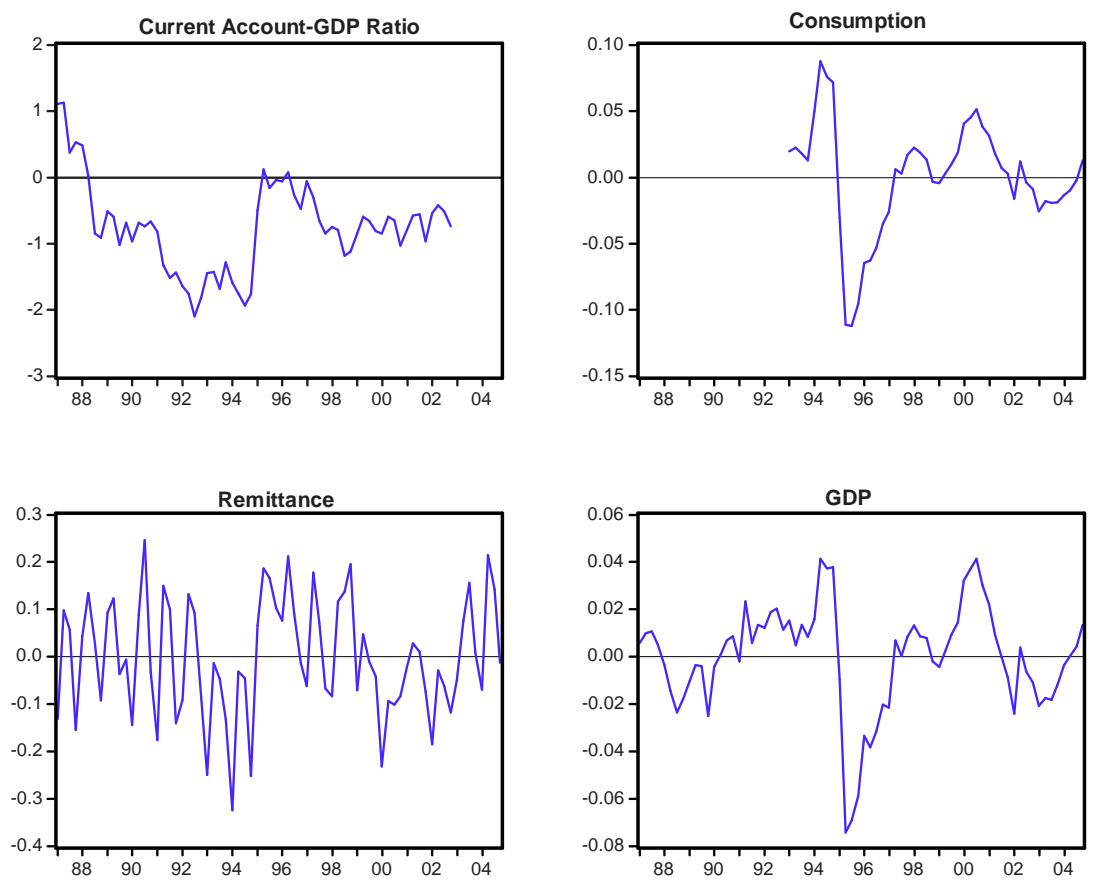

Notes: Data used in the graphs are quarterly seasonally adjusted real series in constant local currency units.

Consumption, GDP, and Remittance data are logged and filtered using an HP filter with a smoothing parameter value of 1600 . The graphs show deviations from trend for these variables. 
Figure 3: Long-Run Distributions of Bond Holdings in the Binding Economy for Turkey

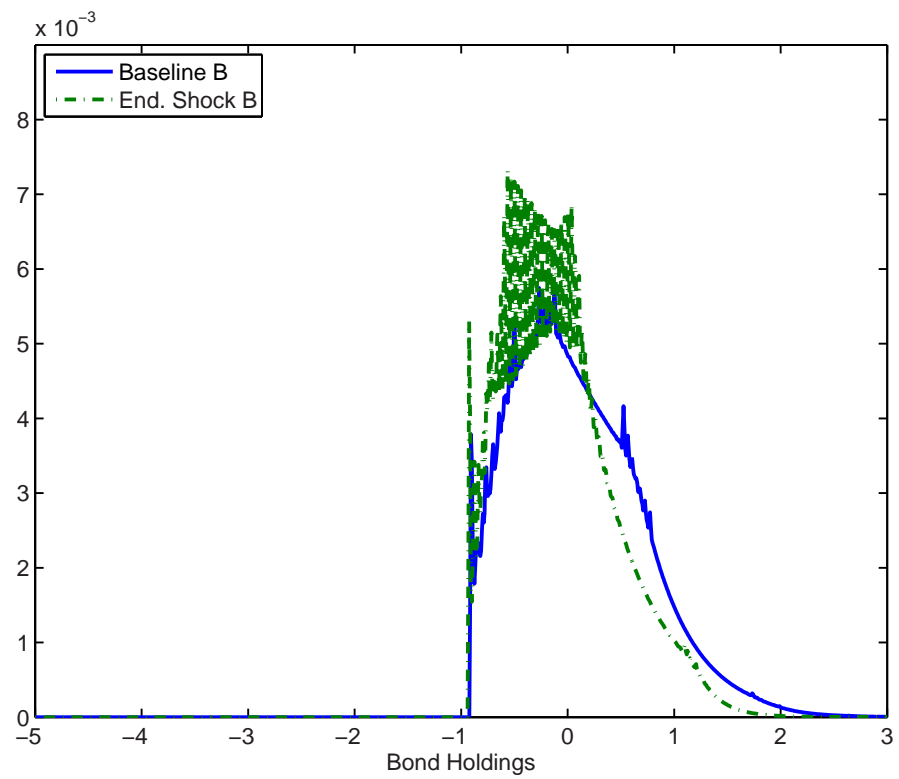

Note: The graphs show the long run distribution of bond holdings in the binding economy with and without remittances shocks. The solid line shows the results for the baseline binding economy. The dashed line shows the results for the binding economy with endowment shocks only.

Figure 4: Long-Run Distributions of Bond Holdings in the Binding Economy for Mexico

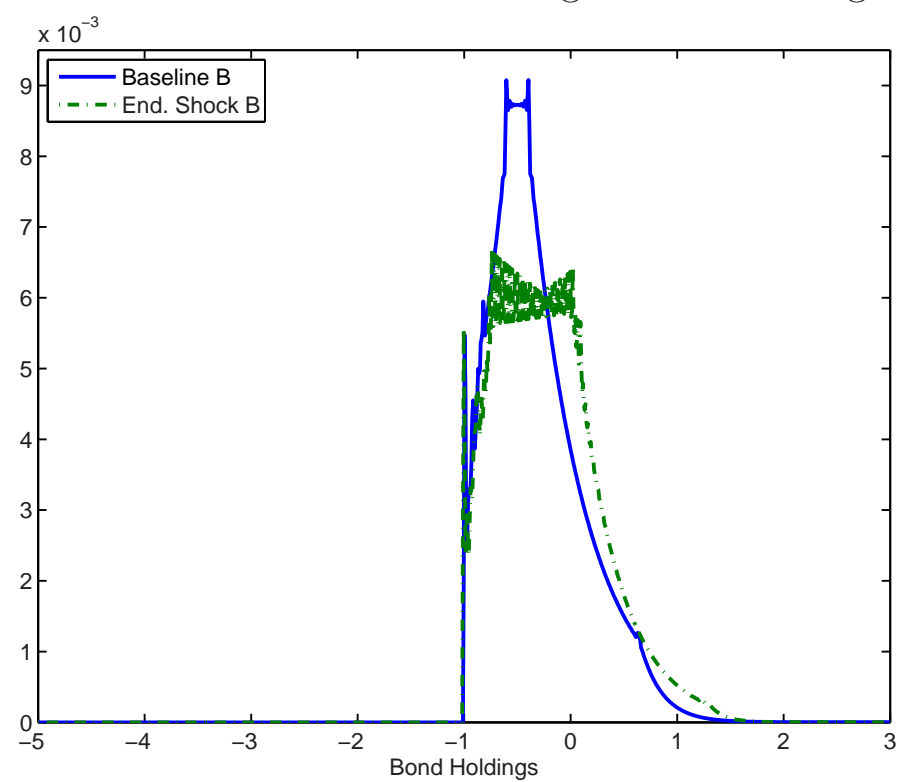

Note: The graphs show the long run distribution of bond holdings in the binding economy with and without remittances shocks. The solid line shows the results for the baseline binding economy. The dashed line shows the results for the binding economy with endowment shocks only. 
Figure 5: Conditional Forecasting Functions in the Model Economy Calibrated to Turkey
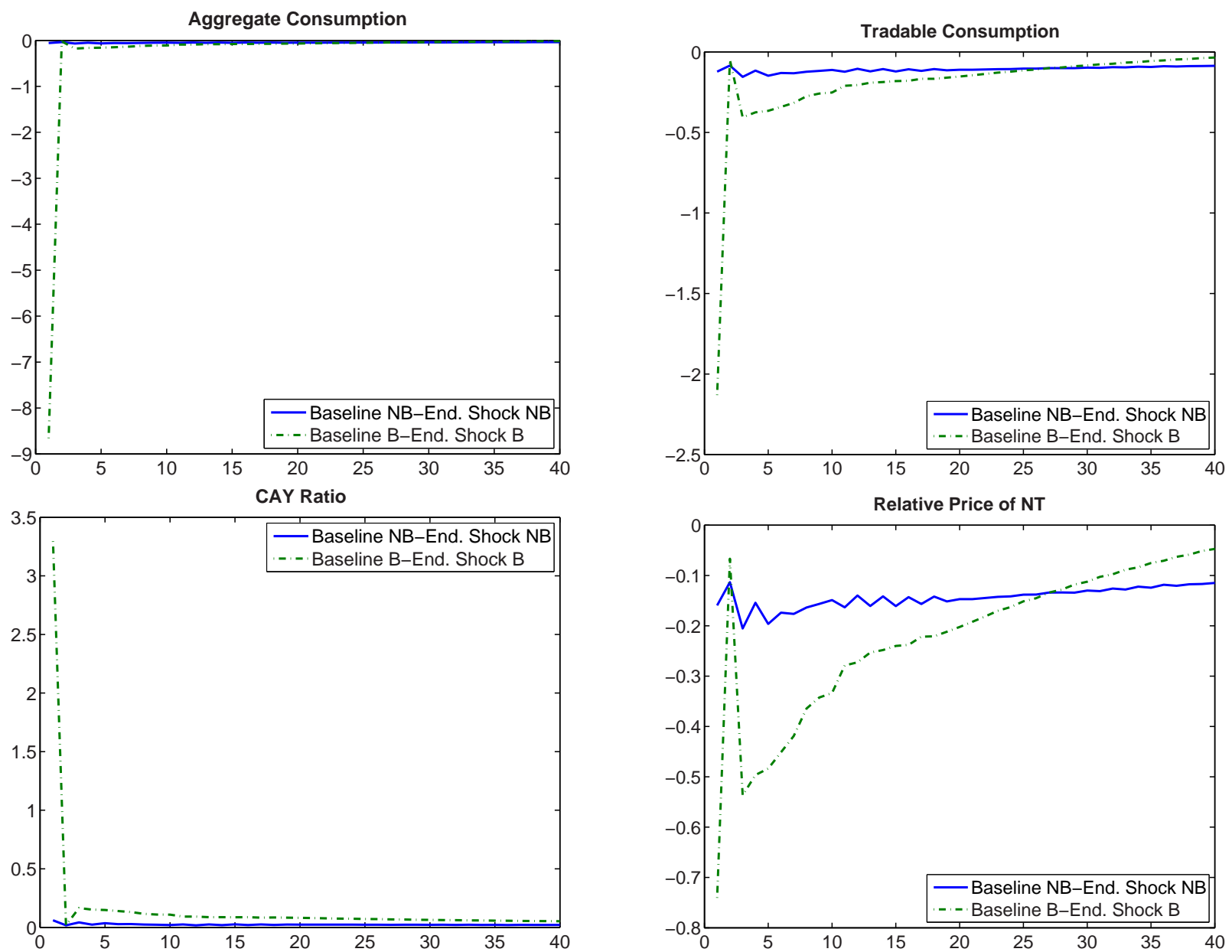

Notes: This figure shows the conditional forecasting functions for aggregate consumption, tradable consumption, current account-GDP (CAY) ratio, and relative price of nontradables. The solid line shows the relative response in the nonbinding economy with both remittance and endowment shocks relative to the nonbinding economy with endowment shock only. The dashed line shows relative response in the binding economy with both remittances and endowment shocks relative to the binding economy with endowment shock only. 
Figure 6: Conditional Forecasting Functions in the Model Economy Calibrated to Mexico
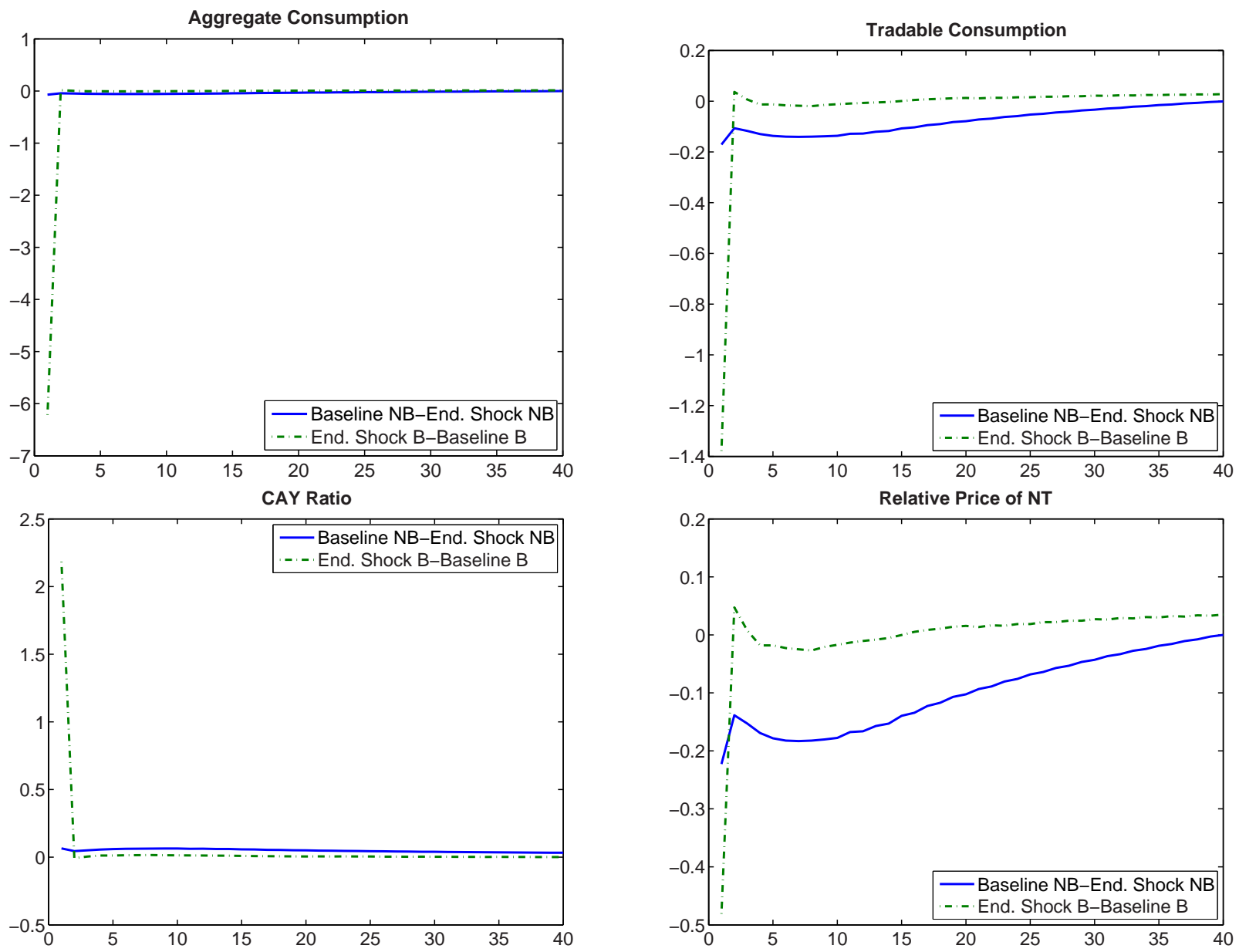

Notes: This figure shows the conditional forecasting functions for aggregate consumption, tradable consumption, current account-GDP (CAY) ratio, and relative price of nontradables. The solid line shows the relative response in the nonbinding economy with both remittance and endowment shocks relative to the nonbinding economy with endowment shock only. The dashed line shows relative response in the binding economy with both remittances and endowment shocks relative to the binding economy with endowment shock only. 